\title{
Opinions of Future Prospective Teachers on Coding Technique
}

\author{
https://doi.org/10.3991/ijet.v15i23.18785 \\ Daniel Sekyere-Asiedu $\left({ }^{(}\right)$ \\ Near East University, Nicosia, Turkey \\ danielasieduapp@gmail.com
}

Nikolay N. Kosarenko

Plekhanov Russian University of Economics, Moscow, Russia

Aliya A. Yergazina

Baishev University, Aktobe, Kazakhstan

Nina A. Petunina

I.M. Sechenov First Moscow Medical University, Moscow, Russia

\author{
Alfiya Sh. Yarullina \\ Kazan Federal University, Elabuga, Russia \\ Grigoriy G. Sidorenko \\ Financial University under the Government of the Russian Federation, \\ Moscow, Russia
}

\begin{abstract}
The use of technology in education has increased rapidly in recent years, and one of these is coding training. Rapid changes have been observed in coding education in recent years. Many countries have added coding-related lessons to their curricula. There are studies about coding education that realise the learning of individuals at a very young age. This rapid change raises many questions for researchers. In this rapidly developing age, the views of prospective teacher candidates on coding are very important. With this study, it is aimed to discover the thoughts of prospective teachers of the Computer and Instructional Technologies Education department on coding education. For this purpose, qualitative data were obtained from 25 pre-service Computer and Instructional Technologies Education teacher candidates with case study method in Northern Cypriot, Russian and Kazakhstani universities. Selections were made based on volunteering among the pre-service teachers who took coding lessons. In this study, the data were collected with the semistructured interview technique, which was developed considering the purpose of the research. Qualitative content analysis was used in the analysis of the data obtained. The results obtained in the research process revealed that the needs of pre-service teachers regarding the coding education were lacking and the number of coding courses should be increased.
\end{abstract}

Keywords - Education, learning, robotic, programme technology, method, computer, coding technique 


\section{Introduction}

Developments in the field of Information and Technology affect not only every area but also the education systems and education programmes of countries. In the information age, individuals have needs that cover a number of high-level skills and learning trends to achieve success in their work and life. These developments in technology have caused radical changes in the educational structure based on the verbal narration of the 20th century [22]. Looking at the latest developments, it encourages educational institutions of technology to be open systems. Educational institutions should be capable of training human resources necessary for professional life in order to maintain sustainability and functionality. With the developing technology, new learning environments have been used in the field of information and communication technologies (ICT), the education system has undergone a structural change, and learning through technology has come to the fore $[3,37,18,28,34,38]$. The most important point among all these changes and innovations is to create techniques and methods used in the transfer of information in the best way possible.

The concept of computational thinking is not new to the educational community. When the Logo programming language was developed for the first time in the 1960s, studies on computational thinking were seen in education. It came out with the coding programme by Logo $[8,15]$. LOGO is derived from the LISP programming language and has been developed to contribute to mathematical problem-solving skills through programming education [26]. Developing problem-solving skills is very important for the development of individuals [1,12]. In recent years, software programmes, such as code, code.org and Scratch, have been re-programmed with visual programming languages [8]. Effective learning of algorithms and flow chart logic are the main purposes of computer-based programming. Before creating the programme, it is necessary to know the algorithm and flow chart of the programme. Algorithms consist of steps that are taken in order to solve a problem. These steps can be visualised by using the flow chart $[2,27]$.

The integration of ICT from all causes into learning experiences creates different needs and materials, especially in teaching. In this context, computer-aided technology has become imperative to teach subjects that require innovative and creative thinking, such as technology and design, and to increase the interest of young people ( $\mathrm{Z}$ generation) living with technological tools, such as mobile applications, tablets, phones, etc. $[14,17,30,32]$. Programming education is a necessary training area for the creation of software, which is one of the basic building blocks for the management of information technologies [6].

The main purpose of robots in education is the subject matter expert who guides the learners in the learning process, a guide to help the teacher or teaching materials. There are two approaches to the use of robots in education. The first approach is the training activities for university-level learners, where robot and robot-related issues, such as robot design, control and artificial intelligence, are the teaching targets. The second approach is the use of robots as a tool for teaching lessons, such as science and mathematics, to learners at A-12 level. These robots are called educational robots. Robots can be programmed with text and block-based programming environments. 
While C, Python and Java are text-based programming environments, Enchanting, Robo Pro, Modkit, miniBlog, Arduino (S4A), Open Roberta, Blocky and mBlock are block-based environments $[9,15,20,21,24]$. Recently, as the importance of coding education has been increasingly understood, 'coding, algorithm, programming and computational thinking' have been heard in every area of daily life.

It has led to the inclusion of coding lessons in primary and secondary education programmes in many countries where 21 st-century skills are available. While some countries add coding education as a compulsory subject to the curriculum, some countries have started to encourage coding to be a part of the teaching activities even if it is not formally a part of the curriculum $[16,25]$. The aim of coding education is to support students to develop their computational thinking skills. The reason why students are taught coding is not to ensure that they are all computer engineers or programmers. In general, the aim is to provide students with the ability to apply and develop their computational thinking skills and to keep up with the technology age $[11,29,33]$. With robotic activities used in education, students participate actively by thinking, questioning and analysing the situation [31].

The most famous software developers Bill Gates started writing programmes at the age of 13, and later founded the 'Microsoft' software company. Mark Zuckerberg, the founder of the social network Facebook, is another software developer who started writing codes at a very young age [4]. The importance of coding education can be realised in transferring information, understanding the design logic of children by learning coding, developing new ideas, implementing the basic ideas, correcting the errors in case of errors and increasing ability to work together [7,13]. In short, it improves problem-solving skills. As a result of raising productive and creative individuals, projects that will change the future, will be introduced by meeting the country's needs in the field of software [21].

Due to the changes in technological development taking place in Turkey and the world of computer science, preparation of new curricula and changes in educational training for teachers and classroom training are required. Therefore, training teachers teaching computational thinking is an important part of the puzzle. Professional development is extremely important for teachers to develop computational thinking pedagogical capabilities effectively [39].

\subsection{Research purpose}

Robotic method which is used in technology-supported education, is one of the new trends used in education today. The aim of this study is to determine the opinions of Computer and Instructional Technologies teacher candidates regarding coding education on robotic coding.

Based on the purpose, the following research questions were posed:

Question 1: What does coding training mean to you?

Question 2: What is the purpose of coding education? Is age important in coding education?

Question 3: Should coding education be given to every student? Why?

Question 4: Do you think there are points that you are missing in developing students' coding skills? 


\section{$2 \quad$ Method}

The qualitative research method was adopted in this research, which aimed to reveal the opinions of information technology and software teachers about coding education. In the qualitative research literature, it is difficult to make a generalised definition for qualitative research. The reason for this is that many concepts under the framework of qualitative research are linked to different disciplines. In this study, interview and document analysis techniques from qualitative techniques were used. This research is a descriptive study and was carried out by interview method, which is one of the qualitative research methods. Mendelli [27] stated that the focus of qualitative research was to help us understand the participants' own perspectives on a situation or a subject and their comments on the subject and the subject.

\subsection{Data collection tools}

In this research, a demographic information form and a semi-structured interview form, consisting of open-ended questions developed by the researchers, were used as data collection tools. Finally, four open-ended questions were addressed to prospective teachers. The open-ended questions in the questionnaire were created by making use of the literature and researchers' own experience. The demographic information form was used to determine the demographic characteristics of the instructor and the interview form was used to determine their opinions about coding. The interview questions were first examined by experts who were experienced in qualitative research by discussing with four faculty members from the Department of Computer and Instructional Technologies, and necessary corrections were made according to the feedback. In that case, a questionnaire was applied to six trainers outside the working group for pilot implementation, and it was checked whether the questions were understandable.

\subsection{Research group}

The participants of the research were senior students of 25 information technologies and instructional design departments in the 2018-2019 spring semester of Northern Cypriot, Russian and Kazakhstani universities. The demographic features of the participants were as follows: 13 females, 12 males; 11 of the final year students attended from Russia, 7 from Northern Cyprus and 7 from Kazakhstan. Maximum variation sampling, which is one of the purposeful sampling methods, was used in the selection of the participants. Purposeful sampling allows in-depth study of information-rich situations in the context of the purpose of the study. The purpose of basing the maximum diversity is not to generalise the situation under investigation by providing diversity, but rather to reflect the partnership or similarities between the diverse situations to the maximum extent [36]. 


\section{Results}

\subsection{What does coding training mean to you?}

'What does coding education mean to you?' The pre-service teachers' views on the question were given in Table 1.

Table 1. Coding themes about education

\begin{tabular}{|l|c|}
\hline \multicolumn{1}{|c|}{ Theme } & F \\
\hline Creativity & 21 \\
\hline Logical and mathematical thinking & 18 \\
\hline Problem-solving & 8 \\
\hline Critical thinking & 7 \\
\hline
\end{tabular}

Regarding the opinion of teacher candidates, almost similar answers were received from all the teacher candidates to the question of what coding education means to them. Twenty-one pre-service teachers said creativity. There were also 18 teacher candidates who stated logical and mathematical thinking skills, 8 teacher candidates stated problem-solving skills, and 7 teacher candidates stated critical thinking.

Some of the pre-service teachers' views were as follows:

S1: 'When we say coding education, the first thing that comes to my mind is creativity. Coding education improves creativity. It provides learning with different perspectives.'

S2: 'Since coding is in a numerical sense, it is a software tool that improves logical and mathematical thinking.'

S3: 'Coding is a learning technique made by increasing productivity. Improves students' and teachers' critical thinking skills.'

\subsection{What is the purpose of coding education?}

"What is the purpose of coding education? Is age important in coding education?" The pre-service teachers' views on the question were given in Table 2.

Table 2. Purpose of coding

\begin{tabular}{|l|c|}
\hline \multicolumn{1}{|c|}{ Theme } & F \\
\hline Productivity & 11 \\
\hline Keeping up with the age & 10 \\
\hline Software specialist development & 4 \\
\hline
\end{tabular}

Regfarding the opinions of teacher candidates for the purpose of coding education, 11 teacher candidates expressed their opinions on productivity and 4 teacher candidates stated developing a software specialist. 
Some of the pre-service teachers' views were as follows:

S1: 'We are at a time when technology is developing rapidly. Robots have become tools that can be used in our daily lives. Nowadays, all the tools are integrated with technology. Coding is indispensable technology. For this purpose, coding education is very important because we have to keep up with the age.'

S2: 'Each code creates a new product. The purpose of coding creates new products. For this purpose, I can say that its main purpose is productivity.'

S3: 'The productive children of the future will be software developers. The purpose of coding is to develop software experts. Individuals who receive coding training will be the productive youth of the future in software.'

\subsection{Should coding education be given to every student? Is age important in coding education?}

The question to computer and instructional technologies senior teacher candidates was 'Should coding education be given to every student? Why?' Their views on the question were given in Table 3. When the importance of coding education is taught at an early age, it contributes significantly to the development of students. For this purpose, in this sub-purpose, while asking the teacher candidates whether coding education should be given to each student, it was also asked whether the age range was important in coding education.

Table 3. Coding lesson

\begin{tabular}{|l|c|}
\hline \multicolumn{1}{|c|}{ Theme } & F \\
\hline Compulsory & 14 \\
\hline Be continuous & 8 \\
\hline Optional lesson & 3 \\
\hline
\end{tabular}

Fourteen teacher candidates argued that the coding education of teacher candidates should be given to all students and that every student should take it. For the coding lessons, eight pre-service teachers stated that it should be taught to the students in elementary schools and as elective courses in secondary and high schools. They also stated that the coding course should be taught in all schools as an elective course by three prospective teachers. Besides these findings, prospective teachers were asked whether age was important or not. Twenty pre-service teachers argued that the earlier the coding lesson was given, the more effective it was. Pre-service teachers stated that coding was effective for problem-solving skills and productivity, so coding lessons given at an early age would develop students in other areas.

\subsection{Do you think there are points that you are missing in developing students' coding skills? What are your suggestions?}

'Do you think there are points where you lack in developing students' coding skills?' The pre-service teachers' views regarding the question were given in Table 4 
Table 4. Coding area knowledge adequacy

\begin{tabular}{|l|l|}
\hline \multicolumn{1}{|c|}{ Not enough (19) } & \multicolumn{1}{c|}{ Enough (6) } \\
\hline Insufficient education & The information provided is sufficient \\
\hline Lack of pedagogical knowledge & \\
\hline In-service training or certificate programmes & \\
\hline
\end{tabular}

When the prospective teachers were asked whether they had any coding deficiencies, 19 teachers stated that the training was insufficient and 6 pre-service teachers stated that the training was sufficient in the coding field.

Some of the teachers' opinions are follows:

S1: 'The number of courses related to coding from the courses we have taken at the university is very low. It is given the opportunity to put new products from our knowledge of application opportunity rather than theoretical contents. I think we should take more lessons about coding.'

S2: 'Pedagogical content knowledge is very important in coding education. I don't feel enough about this. I think I have shortcomings.'

S3: 'I think we should take lessons about coding teaching from the first grade.'

\section{Conclusion and Discussion}

In the opinions received from the teacher candidates, the same answer was received from almost all the teacher candidates to the question of what does coding education mean to them. Twenty-one pre-service teachers said creativity. There were 18 teacher candidates who stated logical and mathematical thinking skills, 8 teacher candidates who stated problem-solving skills and 7 teacher candidates who stated critical thinking. Considering the emergence and requirements of coding education, these results are consistent with other studies. When we look at the rationale of coding education in the literature, it can be seen that they express that teaching concepts, such as problem-solving skill, creative thinking skill, cycle, condition and variable, can be gained to students at this level [5].

Regarding the opinions of teacher candidates for the purpose of coding education, 11 teacher candidates expressed their opinions on productivity and 4 teacher candidates stated developing a software specialist. The aim of coding education is to develop computational thinking skills in students. Wing [33] stated that computational thinking should be learned as a basic skill by everyone. The purpose of coding education is to improve the thinking process, problem-solving skills, creativity, algorithmic thinking, decomposition, abstraction, generalisation and evaluation [23, $10,21,29,33,35]$.

In the opinions received from the teacher candidates, it was concluded that they only need to develop productivity, software specialists and keep up with the age. Studies can be conducted to increase the knowledge and skills of prospective teachers regarding the goals of coding education. Fourteen teacher candidates argued that the coding education of teacher candidates should be given to all students and that every student should take it. For the coding lessons, eight pre-service teachers stated that it 
should be taught to the students in elementary schools and as elective courses in secondary and high schools. They also stated that the coding course should be taught in all schools as an elective course by three prospective teachers.

Besides these findings, prospective teachers were asked whether age was important or not. Twenty pre-service teachers argued that the earlier the coding lesson was given, the more effective it was. Pre-service teachers stated that coding was effective in problem-solving skills and productivity, so coding lessons given at an early age would develop students in other areas. When prospective teachers were asked whether they had any coding deficiencies, 19 teachers stated that the training was insufficient and 6 pre-service teachers stated that the training was sufficient in the coding field. These results are supported by studies and the importance of coding has been proven by studies. Studies can be conducted to increase the knowledge of prospective teachers about coding. University coding courses should be increased and certificate programmes should be given to increase students' coding knowledge.

\section{$5 \quad$ References}

[1] Abdi, M., \& Sharyati, A. (2019). Comparing the training effects of problem-solving and coping skills with stress. Global Journal of Psychology Research: New Trends and Issues, 9(1): 16-22. https://doi.org/10.18844/gipr.v9i1.4110

[2] Aslanyurek, M. (2007). Programlamaya Giriss ve Algoritmalar Ders Notlari.

[3] Atasoy, R., \& Cemaloglu, N. (2018). Evaluation of quality policies on education in Turkish education system. University of Journal Education Research, 6, 1504-1518. https ://doi.org/10.13189/ujer.2018.060711

[4] Aytekin, A., Cakir, F. S., Yucel, Y. B., \& Kulaozu, I. (2018). Gelecege Yon Veren Kodlama Bilimi ve Kodlama Ogrenmede Kullanılabilecek Bazı Yontemler. Avrasya Sosyal ve Ekonomi Arasstirmalari Dergisi, 5(5): 24-41.

[5] Bell, T., Alexander, J., Freeman, I., \& Grimley, M. (2009). Computer science unplugged: School students doing real computing without computers. The New Zealand Journal of Applied Computing and Information Technology, 13(1): 20-29.

[6] Bhuyan, M., \& Tamir, A. (2020). Evaluating COs of computer programming course for OBE-based BSc in EEE program. International Journal of Learning and Teaching, 12(2): 86-99. https://doi.org/10.18844/ijlt.v12i2.4576

[7] Bower, M., \& Falkner, K. (2015). Computational thinking, the notional machine, preservice teachers, and research opportunities. Proceedings of the 17th Australasian Computing Education Conference (ACE 2015), 27(30).

[8] Calao L. A., Moreno-Leon, J., Correa, H. E., \& Robles, G. (2015). Developing Mathematical thinking with Scratch. An experiment with 6th grade students. In G. Conole, T, Klobucar, C. Rensing, J. Konert, \& E. Lavoue (Eds.), Design for teaching and learning in a networked world (pp. 17-27). Lecture Notes in Computer Science, vol 9307. Springer, Cham. https://doi.org/10.1007/978-3-319-24258-3_2

[9] Costelha, H., \& Neves, C. (2018). Technical database on robotics-based educational platforms for K-12 students. 2018 IEEE International Conference on Autonomous Robot Systems and Competitions (ICARSC) (pp. 167-172), IEEE. https://doi.org/10.1109/icarsc. $\underline{2018.8374178}$ 
[10] Cetin, I., \& Toluk Ucar, Z. (2017a). Bilgi isslemsel dusunme tanimi ve kapsami. Y. Gulbahar (Ed.), Bilgi Islemsel Düşünmeden Programlamaya (pp. 41-78). Pegem Akademi. https://doi.org/10.14527/9786052411117.03

[11] Cetin, I., \& Toluk Ucar, Z. (2017b). Bilgi işlemsel dussunme tanimi ve kapsamı. In Y. Gulbahar (Ed.), Bilgi Islemsel Dussunmeden Programlamaya (pp. 41-78). Pegem Akademi. https://doi.org/10.14527/9786052411117.03

[12] Damy, A., \& Plascencia, M. G. L. (2020). Interdisciplinary block of learning challenges. Contemporary Educational Researches Journal, 10(1): 21-27. https://doi.org/10.18844/ cerj.v10i1.4611

[13] Demirer, V., \& Sak, N (2016). Dunyada ve Turkiye'de programlama egitimi ve yeni yaklasimlar. Egitimde Kuram ve Uygulama, 12(3): 521-546. https://doi.org/10.17244/ eku.310232

[14] Chittaro, L., Ieronutti, L., \& Ranon, R. (2004). Navigating 3D Virtual Environments by Following Embodied Agents: a Proposal and its Informal Evaluation on a Virtual Museum Application. PsychNology Journal, 2(1):24-42.

[15] Feurzeig, W., \& Papert, S. A. (2011). Programming-languages as a conceptual framework for teaching mathematics. Interactive Learning Environments, 19(5), 487-501. https://doi. org/10.1080/10494820903520040

[16] Grover, S., \& Pea, R. (2013). Computational thinking in K-12: A review of the state of the field. Educational Researcher, 42(1), 38-43. https://doi.org/10.3102/0013189X12463051

[17] Yang, J. Y., \& Teng, Y. W. (2014). Perceptions of elementary school teachers and students using interactive whiteboards in English teaching and learning. Journal of Interactive Learning Research, 25(1), 125-154.

[18] Inaltekin, T. (2020). Examining secondary students' perceptions of the technology-based learning and teaching in science courses. World Journal on Educational Technology: Current Issues, 12(2), 71-83. https://doi.org/10.18844/wjet.v12i2.4628

[19] Kalelioglu, F., \& Gulbahar, Y. (2014). The effects of teaching programming via Scratch on problem solving skills: A discussion from learners"e perspective. Informatics in EducationAn International Journal, 13(1), 33-50.

[20] Tubagus, M., Muslim, S., \& Suriani, S. (2020). Development of Learning Management System-Based Blended Learning Model using Claroline in Higher Education. https://doi. org/10.3991/ijim.v14i06.13399

[21] Karabak, D., \& Gunes, A. (2013). Ortaokul birinci sınıf ogrencileri icin yazilim geliştirme alanında mufredat onerisi. Egitim ve Ogretim Arastırmalari Dergisi, 21(2-3): 163-169.

[22] Koleda, P. (2020). Innovation of CNC machining education at the Faculty of Technology.New Trends and Issues Proceedings on Humanities and Social Sciences, 7(1), 84-91. https://doi.org/10.18844/prosoc.v7i1.4870

[23] Korkmaz, O., Cakir, R., Ozden, M. Y., Oluk, A., \& Sariogglu, S. (2015). Bireylerin bilgisayarca dussunme becerilerinin farkli degiskenler acisindan incelenmesi. Ondokuz Mayıs Universitesi Egitim Fakultesi Dergisi, 34(2), 68-87. https://doi.org/10.14582/duz gef.641

[24] Malec, J. (2001, Mart). Soler, J., Boada I., Prados, F., Poch, J., Fabregat, R. (2010). A Formative Assessment Tool for Conceptual Database Design Using UML Class Diagram. International Journal of Emerging Technologies in Learning, 5(3): 27-33. https://doi.org/ $\underline{10.3991 / i j e t . v 5 i 3.1402}$

[25] Mannila, L., Dagiene, V., Demo, B., Grgurina, N., Mirolo, C., Rolandsson, L., \& Settle, A. (2014, June). Computational thinking in K-9 education. Proceedings of the working group reports of the 2014 on innovation \& technology in computer science education conference (pp. 1-29), ACM. https://doi.org/10.1145/2713609.2713610 
[26] McNerney, T. S. (2004). From turtles to tangible programming bricks: explorations in physical language design. Personal and Ubiquitous Computing, 8(5): 326-337. https://doi. org/10.1007/s00779-004-0295-6

[27] Mendelli, S. (2019). Determination of mathematics teachers' opinions related to response and solution-based software in secondary education institutions. Global Journal of Information Technology: Emerging Technologies, 9(2): 41-50. https://doi.org/10.18844/ gjit.v9i2.4421

[28] Rizzetto, L., Ricci, S., \& Marinov, M. (2019). MScs in railway transport and logistics: State of the art and perspectives for a new programme. International Journal of Innovative Research in Education, 6(2): 62-67. https://doi.org/10.18844/ijire.v6i2.4407

[29] Selby, C., ve Woollard, J. (2013). Computational thinking: the developing definition. https ://eprints.soton.ac.uk/356481/1/Selby_Woollard_bg_soton_eprints.pdf

[30] Tuncer, M. (2016). Ag toplumunun cocukları: Z kus ag inın kis ilerarası iletis im becerilerinin cok boyutlu analizi. Ataturk Iletişim Dergisi, 10, 33-46.

[31] Ucgul, M. (2017). Egitsel robotlar ve bilgi isslemsel dusunme. Y. Gülbahar (Ed.), Bilgi Isslemsel Dusunmeden Programlamaya (pp. 295-317). Pegem Akademi. https://doi.org/ $10.14527 / 9786052411117.12$

[32] Visvizi, A., Lytras, M. D., \& Daniela, L. (2018). Education, innovation and the prospect of sustainable growth and development. In A. Visvizi, M. D. Lytras, \& L. Daniela (Eds.), The future of innovation and technology in education: policies and practices for teaching and learning excellence, emerald studies in higher education, innovation and technology (pp. 297-305), Emerald Publishing. https://doi.org/10.1108/9781787565555

[33] Wing, J. M. (2006). Computational thinking. Communications of the ACM, 49(3), 33-35.

[34] Yavuz, F., Ozdemir, E., \& Celik, O. (2020). The effect of online gamification on EFL learners' writing anxiety levels: A process-based approach. World Journal on Educational Technology: Current Issues, 12(2): 62-70. https://doi.org/10.18844/wjet.v12i2.4600

[35] Yecan, E., Ozcinar, H., \& Tanyeri, T. (2017). Bilisim Teknolojileri Oggretmenlerinin Gorsel Programlama Ogretimi Deneyimleri. Elementary Education Online, 16(1), 377393. https://doi.org/10.17051/io.2017.80833

[36] Yildirim, A. \& Simsek, H. (2013). Sosyal Bilimlerde Nitel Araştırma Yontemleri (9. Bask1). Ankara: Seckin Yayincilik.

[37] Yildiz, B. (2017). Disiplinlerarasi ogretim yaklasimi: bilgi isslemsel dussunme ve FeTeMM. Y. Gülbahar (Ed.), Bilgi Islemsel Dusunmeden Programlamaya (pp. 319-339). Pegem Akademi. https://doi.org/10.14527/9786052411117.13

[38] Yildiz, E., Alkan, A., \& Cengel, M. (2020). Current trends in education technologies research worldwide: Meta-analysis of studies between 2015 and 2020. New Trends and Issues Proceedings on Humanities and Social Sciences, 7(1): 47-62. https://doi.org/10.188 44/prosoc.v7i1.4867

[39] Barr, V., \& Stephenson, C. (2011). Bringing computational thinking to K-12: what is Involved and what is the role of the computer science education community? Acm Inroads, 2(1), 48-54. https://doi.org/10.1145/1929887.1929905

\section{Authors}

Daniel Sekyere-Asiedu, Doctoral student of department of Computer Information System at Near East University, North Cyprus, Mersin 10, Turkey Email: danielasi eduapp@gmail.com 
Nikolay N. Kosarenko is $\mathrm{PhD}$ in Law and $\mathrm{PhD}$ in Philosophy, Associate Professor of the Department of State Legal and Criminal Law Disciplines at Plekhanov Russian University of Economics (36 Stremyannyi Pereulok, 115093, Moscow, Russia). He is a well-known Russian scientist and has a lot of published articles in Russian and International journals on the problems of law, philosophy and history of Russian law. $\mathrm{He}$ is also interested on the problems of philosophy of education, educational environment, scientific methodology. E-mail: nkosarenko@yandex.ru

Aliya A. Yergazina is $\mathrm{PhD}$ in Pedagogy, Head of the Department of Foreign Languages and Literature at Baishev University (302A Zhubanov Brothers Street, Aktobe, Kazakhstan). Her research interests include the issues of multicultural education, intercultural communication and intercultural experience, cultural and linguistic nterference in the process of intercultural communication as well as future teacher's social responsibility. She has published more than 100 research works in these fields. Email: yergazin1@mail.ru

Nina A. Petunina is a Doctor of Medicine, Professor, Head of the Edocrinology Department at I.M. Sechenov First Moscow Medical University (Sechenov University) (8 Trubetskaya Street, 119991, Moscow, Russia). Her main scientific and professional interests are related to the development of health care education in digital era. She has more than 100 published articles in Russian and International journals. Email: napetunina@mail.ru

Alfiya Sh. Yarullina is PhD in Education, Associate Professor of the Department of English Philology and Intercultural Communication at Kazan (Volga region) Federal University (Elabuga Institute) (89, Kazanskaya Street, 423600, Elabuga, Russia. Her research interests are connected with the problem of professionally significant personal qualities formation. Also, her research interests for the last decade have been largely concerned with the problems of methodology in linguistics and elearning. She has more than 50 articles published in different international journals. E-mail: yarullina-74@mail.ru

Grigoriy G. Sidorenko is $\mathrm{PhD}$ in Technical Sciences, Associate Professor of the Department of Risk Analysis and Economic Security, Financial University under the Government of the Russian Federation (49 Leningradsky prospect, 125993, Moscow, Russia). His research interests for the last decade have been connected with students' project activity and as well as problems of science teacher education. He has more than 50 published articles in Russian and international journals. E-mail: GGSidorenko@fa.ru.

Article submitted 2020-10-01. Resubmitted 2020-10-23. Final acceptance 2020-10-23. Final version published as submitted by the authors. 